\title{
和船人力推進にお污る熟練者の櫓漕ぎ法の分析
}

\author{
高山 久明*・合田 政次* \\ 矢田 殖朗*・山口 恭弘*

\section{Measurement and Quantitative Evaluation of Skill Seaman's Sweeping Force of a "Ro", an Oriental Scull for "Wasen"}

\author{
Hisaaki TAKAYAMA, Masaji GODA, Shigeaki YADA \\ and Yasuhiro YAMAGUCHI
}

\begin{abstract}
In this study we experimented to clarify handling and sweeping method of a "Ro". Using a strain gage attached to the "Ro", we compared the skills of an "expert" seaman (A or A') with those of average skills, the middle (B) and those who have almost no experience (C).

The results were as follows:

1) In the case of the "expert" seaman, the boat headed straight for the target point because push (Osae) and pull (Hikae) rate was relatively constant as was the tension on the "Haya-o". In addition the ship's pitch and roll was very small.

2) Under good sea conditions the average "Haya-o" pulling force was about $30 \%$ of each seaman's body weight. Comparing body weight the maximum value of "Haya-o" for the expert seaman was from $70 \%(\mathrm{~A})$ to $120 \%(\mathrm{~A})$, and "Osae" was $1 / 3$ or less than that of "Hikae".

3) For this study the "Ro" was positioned on the port quarter of the stern. It was found that although the power which moves the blade in the water depends on the position of the "Ro-gui", it was almost equal for "Osae", and "Hikae" when the boat was going straight.
\end{abstract}

\section{1.はじめに}

近年、小型漁船においても近代化の波が押し寄せ、一隻一隻手造りによった従来の木造和船漁舟は、船 外機が搭載されたFRP船の急速な普及によって激減し、櫓ならびに櫓漕ぎ技術も衰退の危機に瀕してい る。こらした中、各地漁村で祭礼および村興し行事の一環として毎年開催されている櫓漕ぎ競争(船ぐろう) は、櫓漕ぎ技術継承にも一役かっている。かつて明治・大正期までの古式捕鯨時代、八丁櫓鯨勢子舟の高 速性を記録した報告 ${ }^{(1)}$ があるが、櫓は現在でも和船漁舟において、舵と推進の両機能を兼ねる優れた人力推 進具であることに変わりはない。また、櫓漕ぎによって古代航海を模擬した渡海実験の成功 ${ }^{(2)}$ は、和船と櫓 のもつ海洋文化の一端を示すものとして、興味深くまた意義深い出来事であった。

以上のように日本の歴史的文化遺産になりつつある櫓および櫓漕ぎ技術であるが、筆者らは、初心者の 慣海性を養い環境にも無害なものとして、その重要性を再度認識し櫓漕ぎ技術の定量的記録を通して保存 する必要があると考えた。

また筆者らは既に端艇競技のオールの漕力を計測した ${ }^{(3)}$ 。櫓はオールと異なり独立で用いられ、舵兼ね

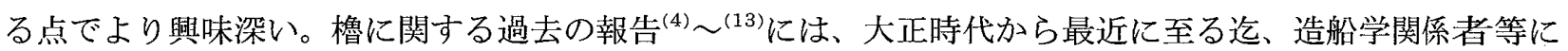

*正会員 長崎大学 水産学部（元852-8521 長崎市文教町1-14） 
よる推進機構、効率など流体力学的評価のほか、起源および分布など歴史的位置付けに関する研究があり、 櫓の推進性能について翼素理論からの取り組みがある。しかし実際の和船操船における櫓漕ぎ技術評価に ついては十分でない。そこで本研究は、櫓漕ぎ技術保存を目的に経験年数の違いによる 3 階層の被験者を 対象に櫓漕ぎ実験を行い熟練者の櫓漕ぎ法を分析した結果、その技術をある程度捕捉できたと考えられる ので報告する。

\section{2. 実験および解析の方法}

被験者は 4 名 $\left[\mathrm{A}, \mathrm{A}^{\prime}\right.$ (熟練者)，B(中級者)，C(初心者)]である。供試船は全長 $5.6 \mathrm{~m} 、$ 幅 $1.4 \mathrm{~m} 、$ 空中重量 約 $250 \mathrm{~kg}$ のFRP和船であり、供試櫓は 10 号櫓*1 (全長 $4.7 \mathrm{~m}$ ) を用いた。また船底の条件は洗浄前の 2 回 (ナギ とシケ) および洗浄塗装直後ナギの海面で 1 回の計 3 回 (実験 1 〜 ) 行った。また各実験直前に曳航による 供試船の抵抗試験を行い、陸側の 3〜4標柱間毎および片道の見通し間距離の所要時間から船速を算定し

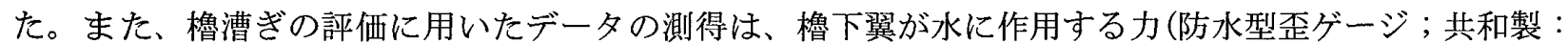
KFW-5-120-C 1-11 L 5 M 2 R) と早緒の張力(共和製：LT-100KG)をそれぞれ動歪計を介して、また 垂直ジャイロから船体運動のRoll, Pitchをデータレコーダ(Teac-R61)に収録した。得られたデータは記 録紙に保存し、周波数分析に供した。

また被験者の櫓漕ぎ法は 正横と船尾の 2 方向から 8 ミリビデオカメラにより撮 影・記録した。実験終了後、 櫓漕ぎ経験や本実験に関す るアンケートを各被験者に 実施した。なお櫓下翼への

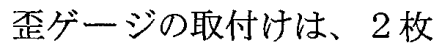

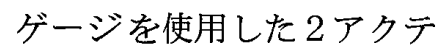
イブゲージ法によった。こ れらの取り付法と校正法 は櫓の各部名称とともに図 1 に示す。

\section{3. 結果および考察}

供試櫓(櫓下翼)の校正結 果を図 2 に示す。図より重 量 $20 \mathrm{~kg}$ までは直線近似でき る。計 3 回の実験時の海況 および供試船への負荷状況 を表 1 に示す。また、図 3 1〜3-3に実験 1 における 被験者 A、BおよびCの櫓 漕ざ一連の動作と実験器材 の配置を示す。図に示すよ らに櫓漕ぎは、櫓の入れ子 部分を支点となる櫓杭に嵌 入させ、船底(敷)から伸び

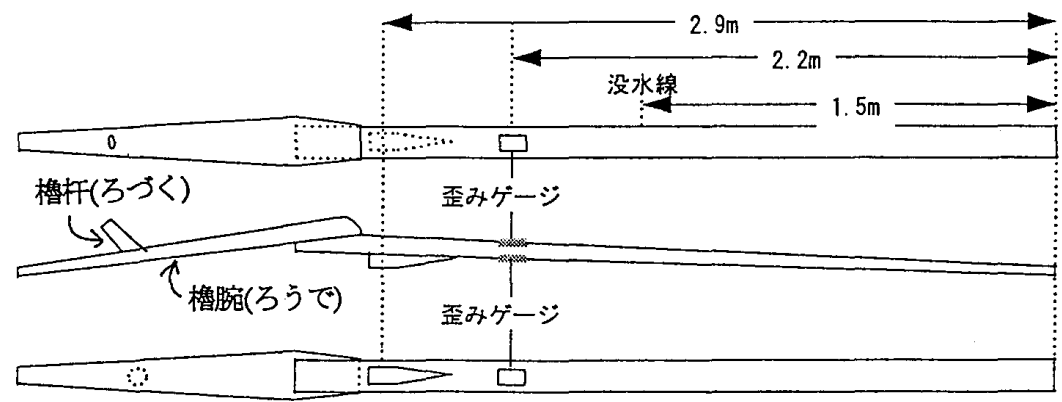

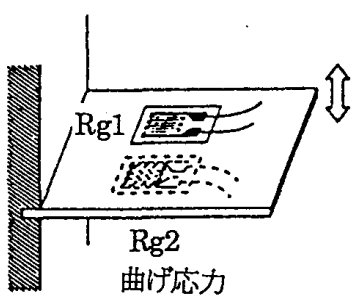
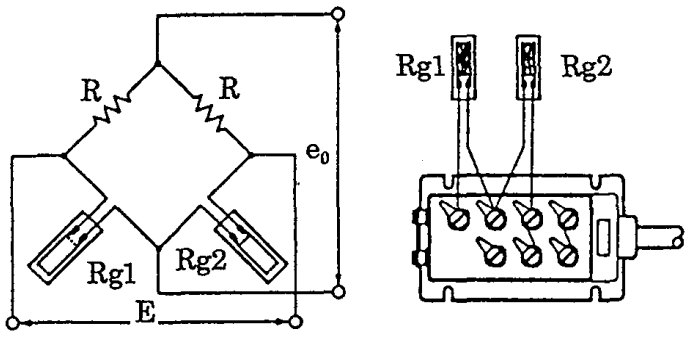

2アクテイブゲージ法(曲げひずみ剆定法)

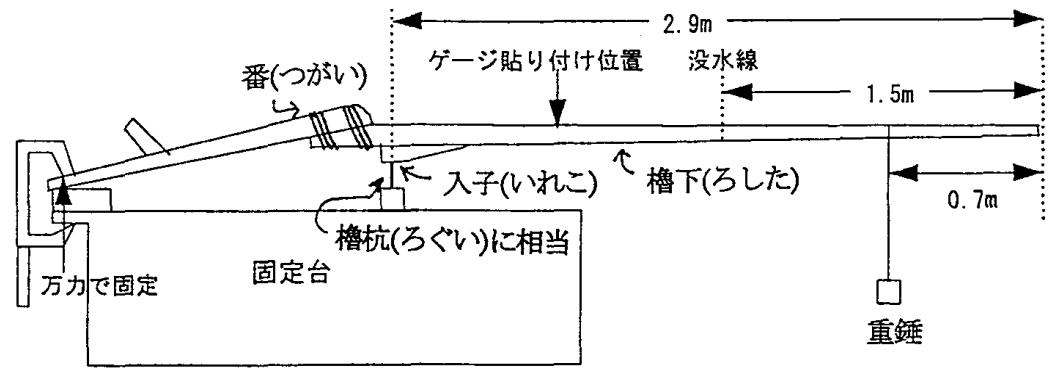

図 1 櫓の各部名称、歪ゲージの取付法及び校正法

*1海上幕僚監部編：短艇教範（海自教範36-01）,pp69-86,1958. 


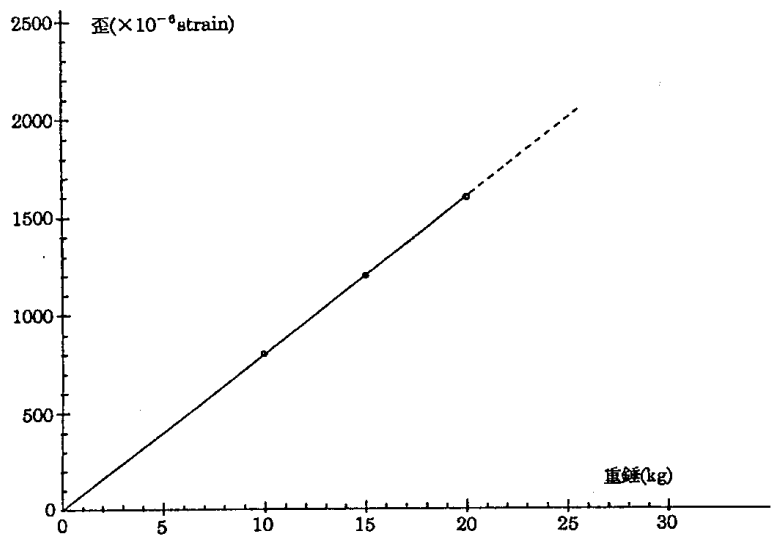

図 2 櫓（歪ゲージ）の校正結果
表 1 実験時の航走距離、供試船への負荷状況及び 海況

\begin{tabular}{|c|c|}
\hline 実谸 1 & \\
\hline ナギ・重量 $88 \mathrm{~kg}$ 搭载 & 距雄 $669 \mathrm{~m}$ \\
\hline 往路(向か心風少々) & 復路(追い風少々) \\
\hline 実瞒 2 & \\
\hline シケ・搭諓重量なし & 距噰 $367.5 \mathrm{~m}$ \\
\hline 往路(追い風・追い波) & 復路(向か心風・向か心い㝿) \\
\hline 実稅 3 & \\
\hline $\begin{array}{l}\text { ナギ・船底洗浄的直 } \\
\text { 往路(Calm 向か、風少 }\end{array}$ & 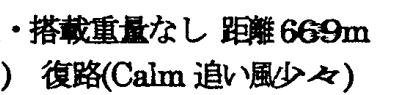 \\
\hline
\end{tabular}

た早緒(細索)を長さ調節して櫓杆に掛け、 その櫓腕部を握り、引き(控え)と押し(押さ え)を交互に行い、水中の櫓下先端部分の同 一片面翼で八の字を描くようにして漕いで 推進する。

3.1 櫓漕ぎ記録波形の一次処理と周波 数分析

櫓漕ぎ記録の一例として実験 3 の記録波 形を図 4 に示す。図から被験者AおよびA' の早緒張力の波形は時間経過に伴ら変化が 少なく、控えの張力がBやCよりも大きく、 押さえはその $1 / 3 に も$ 満たない。このことか ら、櫓漕ぎによる船の直進には控えと押さ えの力配分が異なることが明らかである。 また櫓下翼出力でA'は、和船を直進させる ために櫓の押さえが効き過ぎる点を配慮し たとして抢り、控えの約半分程度の力で漕 いでいた。他の被験者は控え、押さえとも 出力はほぼ等しい。実験中は同一海況であ り、A拉よびA'は出力が全て小さいCと同 様、PitchとRollが小さい。

次に、櫓漕ぎ推進時、櫓に加わる張力な どを櫓さばきと称し、表 2 に示した。すな わち、図 4 の早緒張力および櫓下翼出力の 連続的に出現する各ピーク值50個について 海況の違いも考慮し往路と復路に分け、そ の平均と標準偏差を被験者毎に示し、合わ せて往復のタイム、船速および早緒控え間 の周期を示した。表から、往路 (前半)の向

かい風 (波)時には、速力を維持するためにより力を込めるためか、一般に、大きな出力となっているが、 復路(後半)の追い風(波)時には、比較的楽に漕げるためか出力が小さくなっている。実験 3 では、実験 1 $(88 \mathrm{~kg}$ の重量を船首に搭載、船底が污れた状態)と比較して被験者 $\mathrm{A} 、 \mathrm{~B}$ 小よびCとも船速の上昇が見られ、 この 3 者を平均すれば33\%程度の上昇となった。
表 2 櫓さばき（早緒張力・櫓下翼）と船速に関する計測 結果（ $\mathrm{N}=50 ； \mathrm{kgf})$

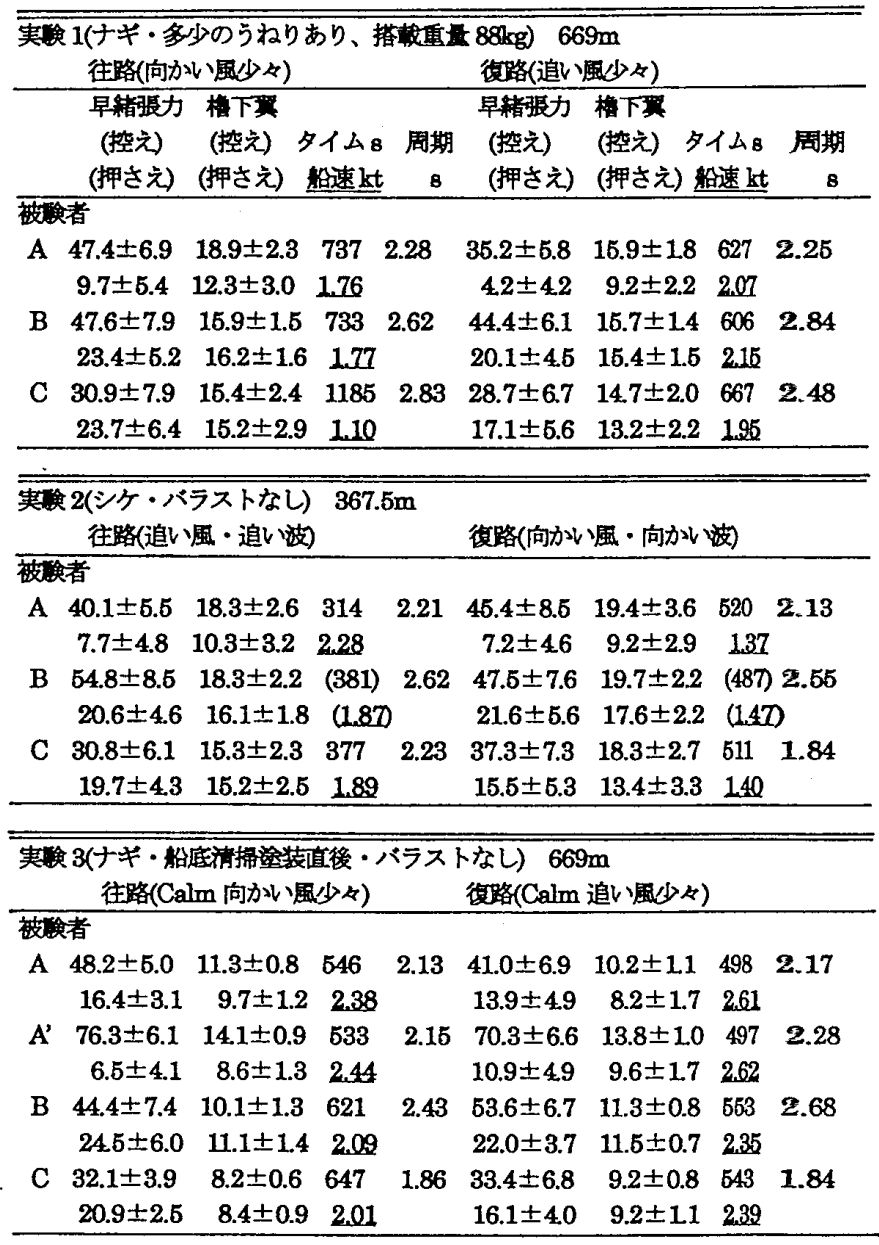

但し、（）内は梅が梅杭からはずれたため劣まで 


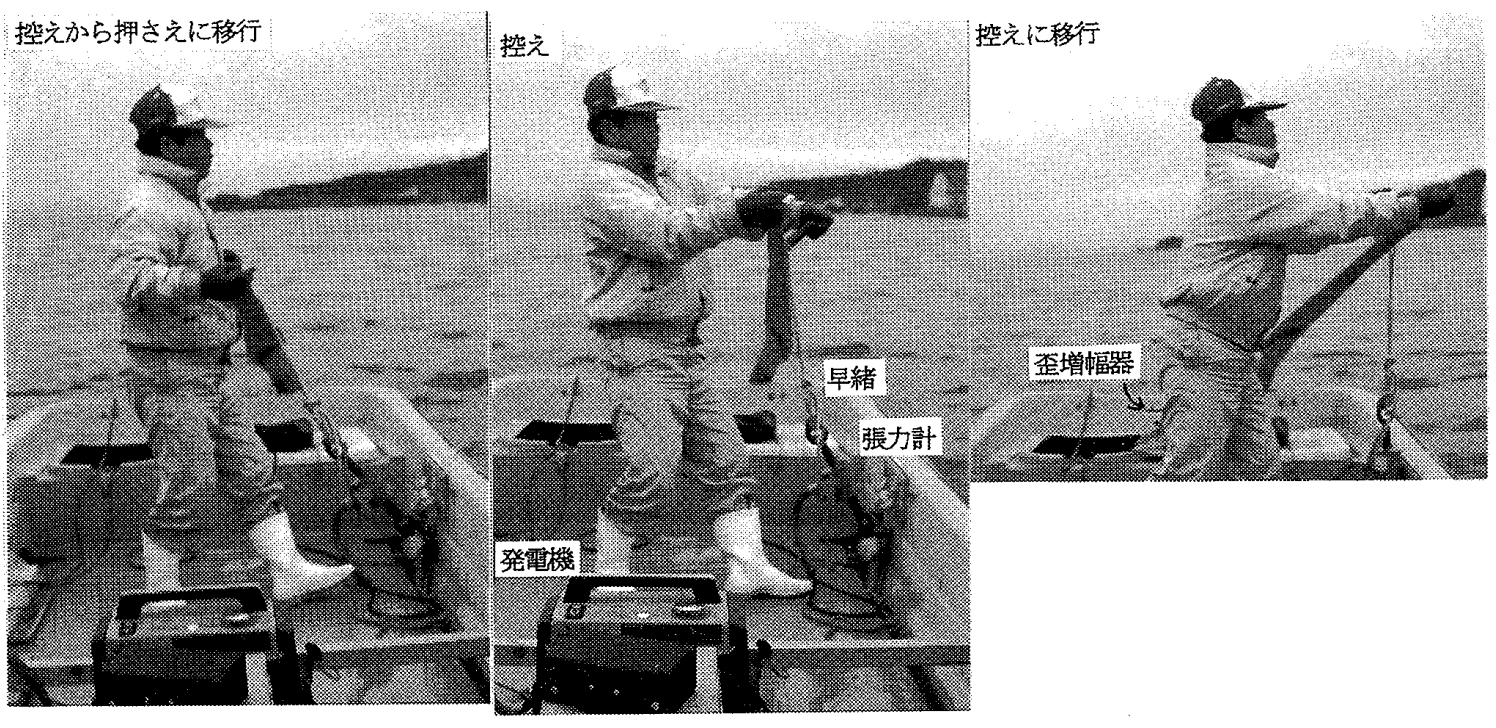

図 3-1 櫓漕ぎの一連動作（被験者 $\mathrm{A} ）$
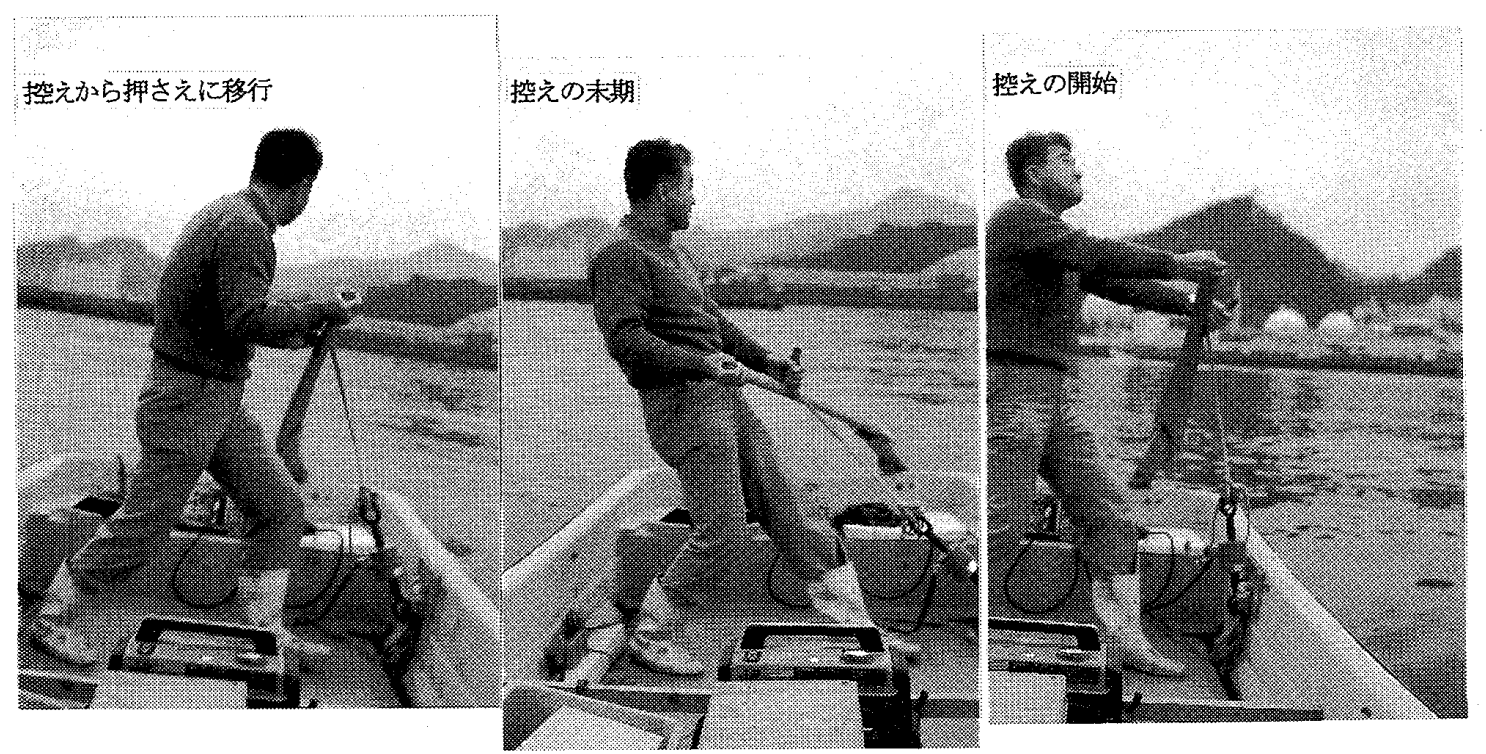

図 3-2 櫓漕ぎの一連動作（被験者 B）

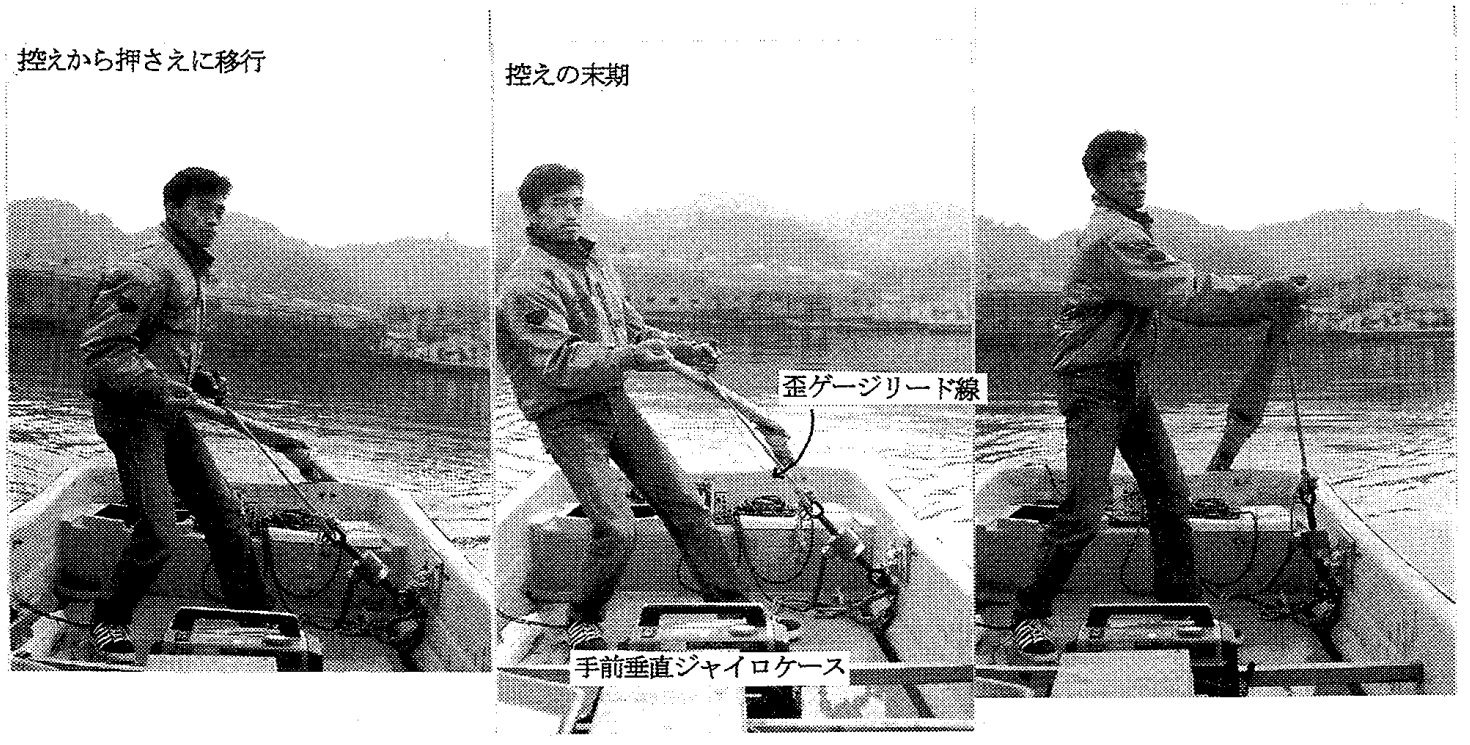

図 3-3 櫓漕ぎの一連動作（被験者 C） 
次に、図 4 に示した 4 種の時系列デ 一タを用い、ラグ数を 30 として周波数 分析を行った ${ }^{(14)}$ 。用いたデータの平均 値と標準偏差を表 3 に示し、実験 3 に おける全被験者の周波数分析結果を図 5 に、また被験者Aの実験1～3におけ る周波数分析結果を図 6 に示す。

図 5 から、早緒張力は被験者A きなピークが一つ現れているのに対し て、他の 3 者は2箇所に現れた。そのう ちA'とBについては周期の長い方に、 Cについては周期の短い方がより卓越 していた。これはCについては櫓漕ぎ において交互に行う控えと押さえの出 力がほぼ拮抗していることを示するの であり、一方のA’および $\mathrm{B}$ がパワー值 の違いはあるものの周波数がより小さ い万にピーク值があることから、ここ では控えがより効いた状態を示している。

次に櫓下翼出力については、全員大きなピーク 值が 1 つ現れ、その周波数は、A と A'で等しく、 Bでは周期が長く、Cでは短い。また、このパワ 一値は、Bが一番大きく、次いでA，AおよびC の順であるが後 3 者に大差はない。

残りの船体動摇ではそれぞれピーク值は 1 つで あり、控えから押さえに至る一連の櫓の動きと一 致した周期を示している。このパワー值はCが一 番小さく、次に A、A'が続き、一番動摇が大きい のがBであった。船速は表 2 にも示した通り、A、 A、BおよびCの順であったから、Bは他 3 者と 比較して櫓下翼で出力された力に対して十分な推 力が得られないか、針路維持に余分な力を費やし たために漕ぎ方にロスが生じた可能性がある。

また図 6 から、被験者A は実験 $1 \sim 3$ とも早緒 張力を除いて残りの櫓下翼の出力、Pitch、Rollの ピーク周波数は一定しており、櫓漕ぎピッチ(リズ 表 3 周波数分析に用いた櫓漕ぎ波形データの平均 值および標準偏差(データ；37.5sec, $\Delta \mathrm{t}: 125$ msec, $N=300$ )

\begin{tabular}{|c|c|c|c|c|}
\hline \multicolumn{5}{|l|}{ 実牙英 1} \\
\hline 被検者 & A & $\mathbf{A}^{\prime}$ & B & C \\
\hline 早腥(kgt) & $13.6 \pm 12.0$ & $\ldots \ldots$ & $18.7 \pm 13.6$ & $13.5 \pm 9.2$ \\
\hline 揞下(kgf) & $5.8 \pm 4.4$ & $\ldots$ & $6.7 \pm 5.2$ & $5.4 \pm 5.0$ \\
\hline Pitch(deg.) & $0.8 \pm 1.0$ & $\ldots \ldots$ & $0.9 \pm 1.1$ & $0.8 \pm 1.0$ \\
\hline Roll(deg.) & $1.0 \pm 1.3$ & $\ldots . .$. & $1.4 \pm 1.7$ & $0.9 \pm 1.0$ \\
\hline \multicolumn{5}{|l|}{ 実絤 2} \\
\hline 被験者 & A & $\mathbf{A}^{\prime}$ & B & $\mathrm{C}$ \\
\hline 早緒(kgef) & $13.6 \pm 11.3$ & $\ldots \ldots$ & $22.7 \pm 15.7$ & $16.1 \pm 8.7$ \\
\hline 掼下(kgf) & $6.2 \pm 4.1$ & ..... & $7.4 \pm 5.4$ & $6.6 \pm 4.9$ \\
\hline Pitch(deg.) & $0.9 \pm 1.2$ & $\ldots$ & $0.9 \pm 1.1$ & $1.0 \pm 1.3$ \\
\hline Rall(deg.) & $2.0 \pm 2.6$ & $\ldots \ldots$ & $1.7 \pm 2.1$ & $1.4 \pm 1.7$ \\
\hline \multicolumn{5}{|l|}{ 実䄼 3} \\
\hline 被㰸者 & A & $A^{\prime}$ & $\mathrm{B}$ & $\mathrm{C}$ \\
\hline 早腥(kgf) & $18.3 \pm 13.1$ & $19.7 \pm 20.6$ & $24.9 \pm 14.3$ & $15.3 \pm 8.8$ \\
\hline 梅下(kge) & $8.5 \pm 5.7$ & $8.7 \pm 6.3$ & $10.4 \pm 6.6$ & $7.1 \pm 5.1$ \\
\hline Pitch(deg.) & $0.5 \pm 0.6$ & $0.6 \pm 0.8$ & $0.8 \pm 0.9$ & $0.5 \pm 0.6$ \\
\hline Roll(deg.) & $1.0 \pm 1.2$ & $1.0 \pm 1.2$ & $1.6 \pm 1.9$ & $0.8 \pm 0.9$ \\
\hline
\end{tabular}
ム) は海況および搭載重量に左右されないことが 伺われる。但し、早緒張力については海況がシケた実験 2 では、通常のピーク周波数の他にその半分の周 波数 (長い周期側)にピークが見られる。これは、パワー值が分散し、通常のナギ時の漕ぎと比較して控え のみを効かして漕いだために相次ぐ控えの約 2 秒を 1 周期とする周波数が強調されたものと推定される。 その他、海況がシケた場合、櫓下翼のパワー值はナギ時と比較してより小さな出力となるが、Pitchおよび Rollは海況の影響により過大となった。

\section{2 和船抵抗試験・櫓漕き速度と有効馬力}

船速と全抵抗值との関係について、曳航試験による結果を図 7 に示す。供試船への負荷条件はいずれも 同一状態 (全体重量 $350 \mathrm{~kg}$ ) として示した。図から実験 2 は、実験 1 と比較して全抵抗值は船速 $2.7 \mathrm{kt}$ 約 $33 \%$ 増加している。また、実験 3 は実験 1 とほぼ等しい海況条件であり、船底洗浄塗装直後のものであったが、 全抵抗值は実験 1 と比較して船速 $2.7 \mathrm{kt}$ で約 $6 \%$ 減少した。ここで、被験者 $\mathrm{A}^{\prime}$ の体重と復路の船速を考慮す 
ると、全抵抗曲線は実験 3 の外側 (下側)に示される曲 線 ${ }^{(15)}$ 〜 ${ }^{(16)}$ となる。これを用 いると、A'の最大船速2.7 $\mathrm{kt}$ の時、全抵抗值は $3.2 \mathrm{kgf}$ と算定できる。これから $\mathrm{A}^{\prime}$ の有効馬力は約 $0.06 \mathrm{ps}$ ある。また $2.7 \mathrm{kt}$ の船速は、 同じ $\mathrm{X}$ 軸に示す $\mathrm{Fn}$ (フルー ド数)では 0.19 となり、低速 ではあるが大型タンカー並 みの船速に匹敵する(16)。

3.3 櫓漕ぎ技術の総合 評洒

被験者 4 名を対象とした 櫓漕ぎに関するアンケート 結果をまとめ表 4 に示す。 表には年齢、体格のほか、
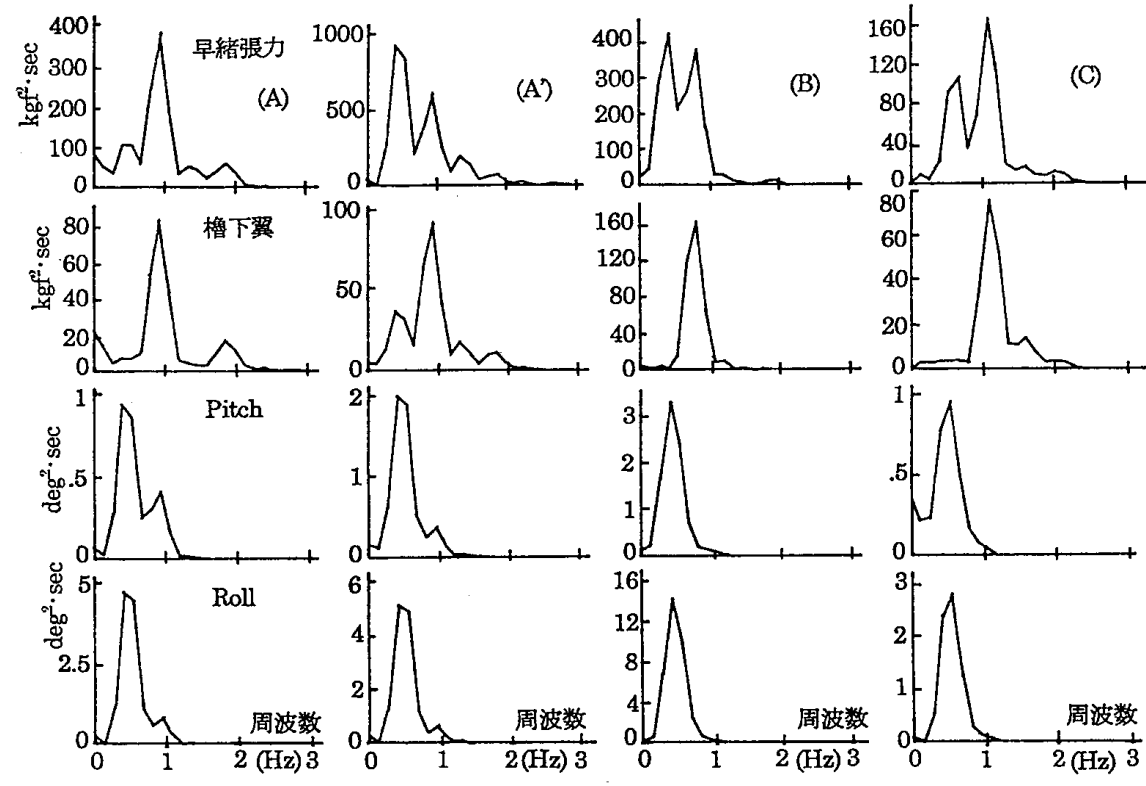

図 5 櫓漕ぎ周波数分析結果（実験 3 、被験者 4 名）

櫓漕ぎ経験、実験時の船や 櫓への対応の仕方および櫓 以外の人力推進具の経験と 櫓漕ぎとの対比について示 している。これによると、 櫓漕ぎ経験において、熟練 者のA、A'はともに小学生 位から遊び等を通じ櫓漕ぎ を経験しており、上達すな わち櫓漕ぎに自信を持てる 迄の期間は 3 ケ月程度と短 かった。その後は時々思い 出す程度の数年に $2 \sim 3$ 回 の経験である。このうちA は船外機のFRP艇を所有 しているが櫓は積んでおら ず、最近は櫓を殆ど漕いで いないとのことであった。

また、実験時の船および

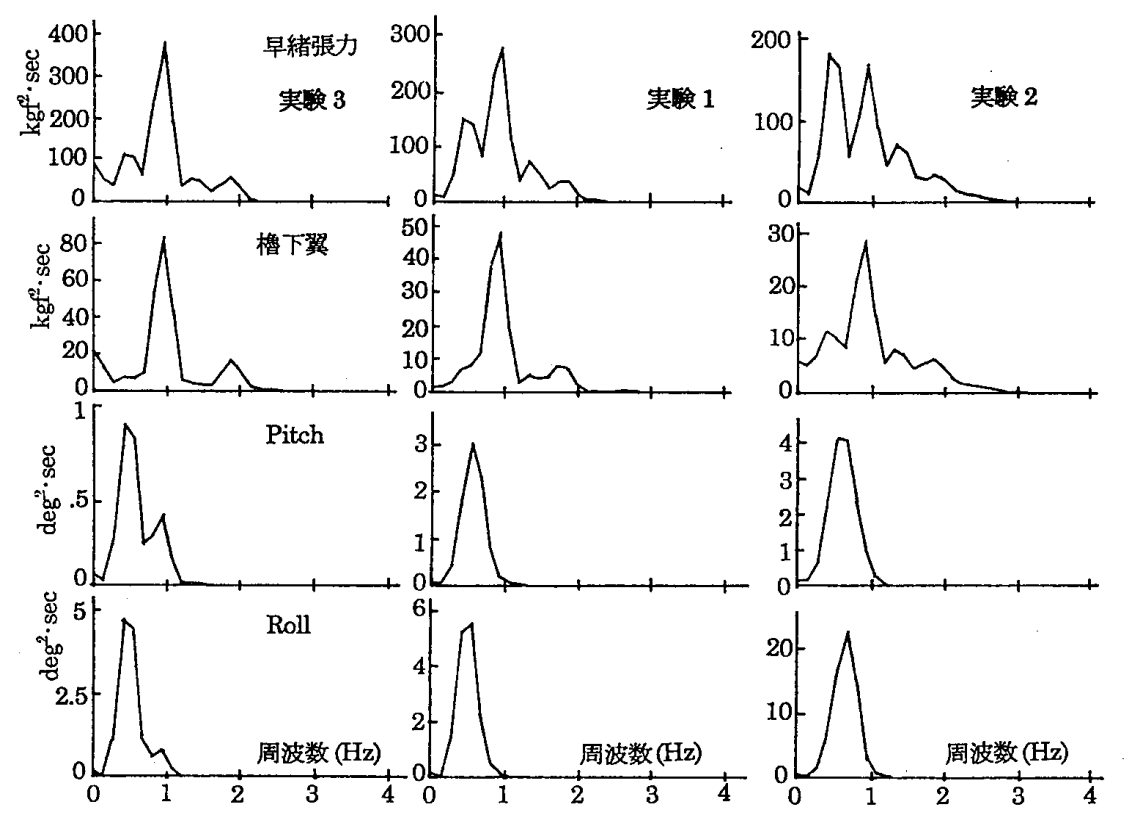

図 6 櫓漕ぎ周波数分析結果（被験者 $\mathrm{A}$ 、実験 $1 \sim 3$ ）

櫓について、中級者・初心

者では良く判らないのではと思える船のくせや櫓の長さの指摘があり、彼等自身の経験からこれらの判断 が容易なのであろう。その他、早緒の長さ(高さ)については臍までの距離が適当であることや左䑳櫓であ るため、左足を前に、両足の間隔は肩幅程度、注意点としては目標に向け、力の整合をはかること等を挙 げていた。また実験の結果、FRP和船が木船より軽いという指摘など、1 回が往復で30分に満たない実験 であったにもかかわらず、これら船と櫓に関する多くの情報を漕ぎを通して収集し、かつ状況に応じた櫓 漕ぎ法を展開したと言える。

また最下欄に示す他の人力推進具の経験であるが、長崎市近郊という地域柄、Aはペーロン櫂のほか、 「ねり櫂」や和船オールの経験を有していた。ねり櫂は櫓と同様に以前小型船の操船に用いられ、前進・後 進が 1 本の櫂で可能な道具である。その中で、櫓はねり櫂と比較して難しくないとしている。A'は、中級 
者のB と同様、ローボートや端艇のオールの経験 を有するが、櫓は慣れており、Bは、一旦こつを 覚えると漕げるとしている。またCは、櫓が端艇 オールと比較し非力でも漕げるとしている。

以上のことから、櫓は小学生位の低年齢に漕法 を習得することが有効である。一旦身についた櫓 漕ぎ法 (seamanshipまたはoarsman-ship)は、長 じて水産・海洋・船舶分野への進出を目指寸場 合、これらに対するセンスを更に極めるためにも 有効に機能することが考えられる。また、幼少時 にこのような機会が得られなかった場合でも、C に見られるように櫓漕ぎ法の習得は、比較的短期 間でも可能と考えられる。

\section{4. まとめと今後の展望}

櫓漕ぎ熟練者を理想的な漕法と仮定すると、以 下の点が望ましい櫓漕ぎ法といえる。

1）ほぼ一定したピッチを持続し、漕ぎに伴う船 体動摇が小さい。

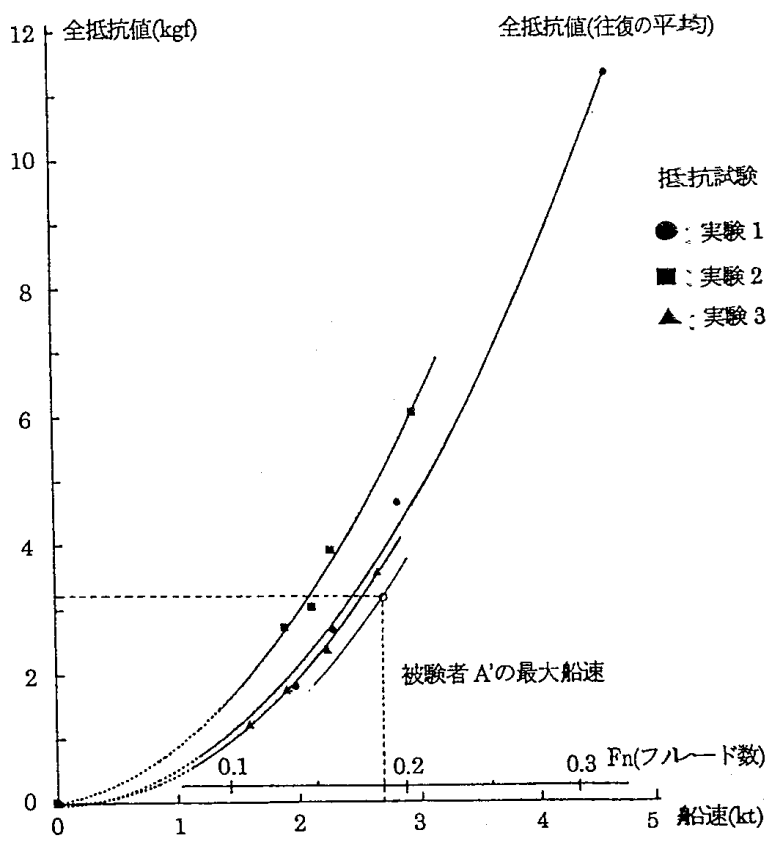

2) 早緒張力の平均值は各被験 者とも体重の約 3 割と見なさ れる。また瞬間最大值では、 押さえの力は控えの $1 / 3$ 以下 である。

3）櫓下翼の水への作用力は、 直進時には控え・押さえはほ ぼ等しい。 また、熟練者の櫓漕ぎ経験を 振り返ると、遊び等を通じ幼少 時からの経験を有しており、上 達までの期間は短かく、一旦身 についた櫓漕ぎ技量は年輩にな っても容易に再現可能であっ た。

今後は、櫓漕ぎの際の映像解 析や船・櫓の条件の違い、熟練 被験者数を増やすなど櫓漕ぎ熟 練技術データの更なる蓄積と普 遍化を予定している。これらの 数量化により、橹漕ぎ技術の保 存とともに櫓漕ぎ上達法のノウ 八ウを示し、次世代に伝えたい 表 4 櫓漕ぎ経験等に関するアンケート結果

\begin{tabular}{|c|c|c|c|c|}
\hline 被験者 & A & $\mathrm{A}^{\prime}$ & $B$ & $\mathrm{C}$ \\
\hline 年齢 & 56 & 48 & 44 & 23 \\
\hline 体格 身長(cm) & 152 & 162 & 174 & 168 \\
\hline 本重 $(\mathrm{kg})$ & 60 & 62 & 77 & 52 \\
\hline 腈高さ cm & 85 & 97 & 102 & $\ldots$ \\
\hline 開始年龄才才) & 12 & 7 & 19 & 19 \\
\hline 上達迄” (歳月) & 3ケ月 & 遊びに使用? & 訓練·指導練習(10 & 0 年) - \\
\hline (年齢) & 13 & 13 & 35 & -. \\
\hline その後 & 年 $2 \cdot 3$ 回 & 訓練等 3.4 年に数原 & 回 (同左) 実験 & 嗆迄十数回 \\
\hline \multirow{7}{*}{ 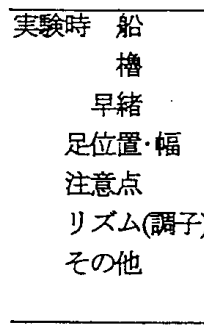 } & 普通 & 押さえ効きすぎる & 万普通 & -- \\
\hline & 適当 & や队短い & 適当 & 適当 \\
\hline & 腈位䁖適当 & 適当 & 適当 & 適当 \\
\hline & 左前·屃幅 & 左前·肩幅 $(40 \mathrm{~cm}$ & n) 左前·肩幅 & 左前·商幅 \\
\hline & 目標向け & 目標向け·力の整合. & 大きくゆったり & 擼杭のはずれ・目標 \\
\hline & ）自然体 & 特になし & 大漁節 炡 & 押え·控え同しに \\
\hline & 1 時間 OK & $\begin{array}{l}\text { 左手マメ、疲れた } \\
\text { 船よ木船より軽い }\end{array}$ & $\begin{array}{l}\text { 波ある所大変 } \\
\text { 直進困難·疲れた }\end{array}$ & $\begin{aligned} & \text { 船右偏のため } \\
= & \text { p队左へ·波困難 }\end{aligned}$ \\
\hline \multicolumn{5}{|l|}{ 人力推進具経垔 } \\
\hline ペーロン & 0 & $\cdots$ & $\cdots$ & - . \\
\hline ローボート & $\cdots$ & 0 & 0 & $\ldots$ \\
\hline ねり櫂 & 0 & $\cdots$ & $\cdots$ & $\cdots$ \\
\hline オール & ○和船 & 0 & 0 & 0 \\
\hline 全体所感等 & 社り擢团難 & 安心して操作可能 & $\begin{array}{l}\text { 椎は慣れたくいる } \\
\text { こつを覚えると浀 }\end{array}$ & 槽げる 非力でも OK \\
\hline
\end{tabular}
と考えている。

\section{謝 辞}

本研究を行うにあたり、櫓漕ぎ被験者 $(\mathrm{A})$ としてご協力いただいた、長崎県西彼杵郡時津町、久米三男 
氏にお礼申し上げます。また、同じく櫓漕ぎ被験者であり実験補助者として協力いただいた、当時、長崎 大学水産学部 4 年次生の射場康博氏にお礼申し上げます。

\section{参 考 文 献}

（1）熊野太地浦捕鯨史編纂委員会編：熊野の太地，鯨に挑む町，p351，平凡社，1969.

（2）日韓友好親善の船編：絶海を渡る一七丁櫓地舟による朝鮮海峡横断の記録一,「日韓友好親善の船」発 行所, 1987.

(3) 高山久明 - 矢田殖朗 - 山口恭弘：端艇の人力橈漕における漕力の計測と評価, 日本航海学会論文集, 第99号, pp189-196, 1998.

（4）横田成年：Action of “Ro(櫓)”，造船協会会報，第28号，pp49-56，1921.

(5) 藤本武助：櫓の話,「舵」発行所, 13巻 9 号, pp350-357, 1934.

(6) 宮田勝善：橈と櫓,「舵」発行所, 1943.

(7) 山縣昌夫：船型学推進編, pp34-35, 天然社, 1952.

（8）西山哲男：和船に於ける櫓の流体力学的解析, 西部造船会会報, 第 12 号, pp30-40, 1956.

(9) 松木 哲：イギリス海軍と櫓, 海事史研究, 第25号, pp71-74, 1975.

(10) 田草川善助：櫓について，東北民俗，第20号，pp3-8，1986.

(11) Azuma, A., Furuta, T., Iuchi, M. \& Watanabe, I. : Hydrodynamic Analysis of the Sweeping of a "Ro"-an Oriental Scull, Journal of Ship Research, Vol.33, No.1, pp47-62, 1989.

(12) 池畑光尚 - 田草川善助：櫓漕の推進性能に関する水槽実験, 日本造船学会論文集, 第172号, pp287297, 1992.

(13) 池畑光尚：櫓漕の推進性能に関する翼素理論による計算, 日本造船学会論文集, 第178号, pp93-99, 1995.

(14) 赤池弘次・中川東一郎：ダイナミックシステムの統計的解析と制御, $\mathrm{pp} 30$ 189, サイエンス社, 東京, 1978.

(15) 高山久明：在来型漁船 (和船) の性能に関する研究-- I, 和船模型の抵抗実験, 日本航海学会論文集, 第 78号, pp83-94, 1988.

(16) 高城 清: 実用船舶工学, pp149-189, 海文堂, 東京, 1975.

\section{質 疑 応 答}

定兼廣行(神戸商船大学)：櫓を漕ぐ場合、櫓の握り方ですが、これは熟練者と初心者とで違いがあるので しょらか。写真で示された方法は熟練者む初心者も左手で櫓杆を握り、右手は逆手で櫓腕先端を握って いるように見受けられますが、これは正しい握り方なのでしょうか。私の経験等から両方とも順手か、 もしくは左手が櫓杆を握った場合、一方の右手は順手または同様な順手に近い持ち方で櫓腕先端を掴む ようにして握り、押さえ・控えの動作に合わせ手首を効かして漕いでいたように記憶していますが。

高山久明：ご質問有難うございます。ご指摘の櫓の握り方ですが、実験に際し、熟練者・初心者とも特に 指定したり、注文は出しておりません。櫓の握り方は、各人がそれぞれ身につけたもので行っており、 それがお示し致しました図(写真)では、各被験者とも同じ握り方(左手で櫓杆を握り、右手は逆手で櫓腕 先端を握っていた)でした。ご質問の件について、私の認識が不確実であるため、後日実験のビデオを見 直したり、各被験者にお尋対して回答させていただきます。

各被験者の櫓の握り方について、実験のビデオで確認したり、被験者にお尋ねしたところ以下のよう でした。

1. 左手は全員櫓杆を握っていた。

2. 右手について、Aは櫓腕先端を手のひらで掴むように握っていた。A'は、櫓腕先端の内側部分を順 手で握っていた。Bは櫓腕先端の内側部分を逆手で握っていた。Cは B と同様。

3. 被験者の櫓の握り方に対する所見。A：控え、押さえの両方に十分な力を出すのに櫓腕先端を手の ひらで掴む握り方が一番良い。経験からこの握り方を習得した。A'：一般的には両手とも順手で握 る。漕いでいて余裕が出たり、ゆったり漕ぐ場合、控えで右手を逆手に握りかえることがある。 B : 
カッターを漕いでいた時、右舷であったので、オールの握り方が内側の手、即ち右手が逆手でグリ

ップを掴んでいた。よって櫓を漕ぐ場合も自然にこの握り方になっていたが、自分自身では、櫓を 漕ぐにあたり持ち方を特に意識したことはなかった。

以上から、櫓の握り方については、ご指摘の通り、両手とも順手で握るか、左手で櫓杆を握った場合、 右手は同様な順手に近い持ち方で櫓腕先端を掴むようにして握り、押さえ・控えの動作に合わせ手首を効 かして漕ぐことが一般的と思われます。 